\title{
橋梁振動を対象とした同調質量系発電デバイス の構造形式と設計に関する検討
}

\author{
竹谷 晃一 1 佐々木 栄一2 \\ 1学生会員 東京工業大学博士課程土木工学専攻（干152-8550 東京都目黒区大岡山2-12-1 M1-23） \\ E-mail: takeya.k.aa@m.titech.ac.jp \\ 2正会員 東京工業大学准教授 土木工学専攻（同上） \\ E-mail: sasaki.e.ab@m.titech.ac.jp
}

\begin{abstract}
橋梁振動を対象とした同調質量系発電デバイスを提案するとともに，その基本特性について検討した. 同調質量系発電デバイスは，従来橋梁の制振のために設置される同調質量ダンパー（TMD）を応用し，ダ ンパーが吸収する振動エネルギーをもとにEnergy Harvesterとして活用するものである. 本研究では, 橋梁 振動を対象とした同調質量系発電デバイスの有利な装置構成と設計に関する検討を行うため, 単質点系と 二質点系の同調質量系発電デバイスを提案し, 解析を行った. その結果, 二質点系は発電装置の減衰比に 対する鋭敏性が小さく, 蓄電において有利であることを導いた. 微変動する橋梁の固有振動数に対しても, 二質点系はパラメータ設計によって柔軟に対応できることを示した.
\end{abstract}

Key Words : bridge vibration, energy harvesting, tuned mass damper (TMD), electromagnetic transducer

\section{1. はじめに}

橋梁の損傷を早期に発見するため, ワイヤレスセンサ などを用いたへルスモニタリングシステムが重要視され ているが, システムの長期的な電源供給が課題の 1 つな っている. その解決方法として注目されているのが，近 年, 様々な分野で研究開発が活発に進んでいる環境発電

(Energy Harvesting) である. 橋梁振動を利用した環境発 電によって, 課題となっているモニタリングシステムの 電源供給のほか, 発電エネルギーをバッテリーへ蓄電す ることで様々な応用も期待できる1).

これまで，劣化や騒音の原因である橋梁の振動を制御 するため, 同調質量ダンパー(Tuned Mass Damper: TMD) や衝擊吸収ダンパー2)の設置が検討されているが，その中 でTMDに着目すると，TMDのダンパーを発電装置 (Transducer) で置き換えて振動エネルギーを積極的に吸 収, 電気エネルギーへと変換することで，TMDの吸収エ ネルギーを利用した環境振動発電が可能となり得る。し かしながら, 橋梁の固有振動数は一般に数Hz程度であり, 環境振動発電の主な対象である機械振動に比べると非常 に低く，発電が困難であった。これまでにも実構造物の 振動を利用した発電デバイス ${ }^{3-5)}$ が開発されているが, 一 般的な橋梁に発生する0.1 1mmオーダーの振動振幅に対
して $\mu \mathrm{W}$ mWレベルの発電電力より高い発電性能が求め られている. 加えて, 橋梁の固有振動数は交通状況や気 温などによって変化するため, 固有振動数変化に対する 発電性能を維持できる設計が課題であった。

現状，発電が困難とされる低周波数の振動を対象とし た環境振動発電)や, 発電した電力をワイヤレスセンサに 供給できるシステムの開発》が試みられているが, これら の取り組みでは, 対象としている振動振幅が数十ミリオ ーダーと橋梁の振動振幅に比べて大きいため, 一般的な 橋梁に発生する0.1 1mmオーダーの振動振幅に適用する ことは難しい，低周波数を対象とした環境振動発電の場 合, 発電による減衰力が高周波数域に比べて小さくなる

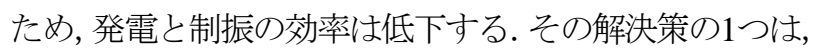
発電による減衰力が大きい高性能な発電装置を環境振動 発電デバイスに適用することである. 近年, 電磁誘導8),99

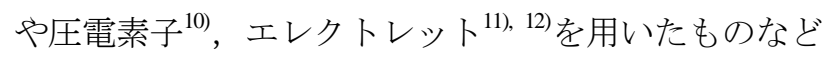
様々な発電装置が開発されており, 発電効率も向上して いる. その中でも電磁誘導タイプは発電電力が比較的高 く, 発電による減衰力が大きいため, 高性能な電磁誘導 タイプの発電装置を用いることで橋梁の低周波数の振動 でも必要な減衰力が得られると考えられる ${ }^{13), 14) .}$

環境振動発電デバイスの構造形式は多種多様で, 同調 質量系や片持ち梁型などの環境振動発電デバイスが代表 


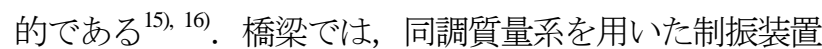
として先に述べたTMDがあるが，これは質量・ばね・ダ ンパーの適切な動力学的バランスの下で, 振動に対して 良好な効果が得られることが知られている。これまでに TMDのモデリングから理論や数值解析, 実用算定式など 振動制御の最適化手法が数多く提案されている ${ }^{17)-23)}$ が, これらのモデリングは，発電を目的とした同調質量系の 発電デバイスにそのまま適用することはできない. TMD を環境振動発電に応用した同調質量系の発電デバイスに 関して, Tang and Zuo ${ }^{24)}$ は単質点と二質点の同調質量系発 電デバイスのモデリングを行い，構造形式について比較 を行った。 その結果，同調質量系発電デバイスに直接調 和外力や変位を与える条件下では, 減衰比を増加させる ことで発電電力が増加できる二質点系が有利と結論付け ている. しかしながら，橋梁においては外力や変位が発 電デバイスに直接作用しないことから, 発電電力はある 減衰比で極大值を持つと考えられるため, 同調質量系発 電デバイスの有利な装置構成について詳しく検討する必 要がある.

一方，電磁誘導を用いた発電装置の発電による減衰力 については，ダッシュポッドでモデリングして環境振動 発電の解析を行う方法 ${ }^{25)}$ があるが，実際には発電装置の 力率から生じる電流の位相遅れの影響で減衰力にも位相 差が生じるため, 発電電力や振動制御特性が異なること が予想される. 加えて, 発電電力をキャパシタや二次電 池に蓄電する場合, 発電による減衰比が時々刻々変化す るため, 減衰比に対する鋭敏性の分析も重要である.

そこで本研究では, 橋梁振動を対象とした環境発電デ バイス (Energy Harvester) として，TMDのダンパーを電 磁誘導型の発電装置に置き換えた同調質量系発電デバイ スを考え，単質点と二質点の同調質量系発電デバイスの 比較から有利な装置構成について検討し, 制振と発電効 率の減衰比や橋梁の固有振動数変化に対する鋭敏性, 力 率による影響など同調質量系発電デバイスの設計に関す る特性を明らかにした。

\section{2. 単質点同調質量系発電デバイス}

はじめに，図-1に示す単質点系の同調質量系発電デバ イス一橋梁に関して解析を行う。すなわち，ばね定数 $K$ のばねと減衰定数 $C_{M}$ のダンパーで支持された橋梁の等 価質量 $M$ があり，等価質量 $M$ には，ばね，電磁誘導型の 発電装置および1つの質量で構成された単質点同調質量 系発電デバイスが付加されている．質量 $M$ に調和外力 $F(t)=F_{0} \sin (\omega t)$ が作用した時, 質量 $M$ の変位を $X(t)$, 単 質点同調質量系発電デバイスの質量 $m_{1}$ の変位を $x_{1}(t)$ と する. $m_{1}$ のMに対する質量比 $\mu_{1}$ は, 通常TMDでは約 $10 \%$
で検討が行われるが，本研究では振動発電と振動制御の 両面を考えており, デバイスの小型化を考慮して約1\%。を 主なターゲットとして検討を行うこととした。発電装置 による減衰力 $F_{e}(t)$ は発電装置内部の構造と接続した電 気回路によって性質が変わるため, 発電装置と電気回路 も含めて設計する必要がある.

図-2に発電装置の等価回路と抵抗 $R$ を有する同調質量 系発電デバイスの電気回路を示す. ファラデーの電磁誘 導の法則より, 電磁誘導型発電装置の起電力 $E(t)$ は磁界の 変化速度 $d \phi / d t$ と発電装置の振動速度 $d x / d t$ に比例する と考えると, 起電力と発電装置の振動速度の関係は次の ように表せる.

$$
E(t)=k_{\text {emf }} \frac{d}{d t}\left\{x_{1}(t)-X(t)\right\}
$$

$k_{\text {emf }}$ は速度に対する起電力の比を表す定数值で, 誘導起 電力係数 $[\mathrm{V} . \mathrm{s} / \mathrm{m}]$ と呼ぶ. 図-2のように電磁誘導方式発電 装置の等価回路を考えると回路式は次のようになる.

$$
E(t)=(R+r) I(t)+L \frac{d I(t)}{d t}
$$

発電装置による減衰力 $F_{e}(t)$ のように表せる.

$$
F_{e}(t)=k_{e m f} I(t)
$$

電気回路におけるエネルギ一損失は内部抵抗 $r$ にる消 費エネルギーと等しい. ここで,一般性を持たせるため, 次の無次元項を導入する.

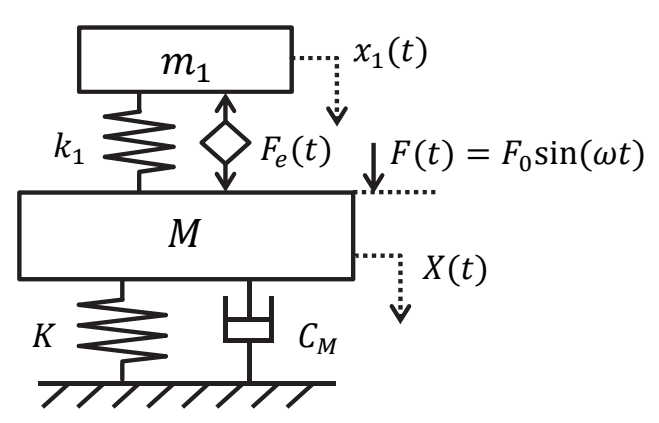

図-1＼cjkstart単質点同調質量系発電デバイスと橋梁の解析モデル

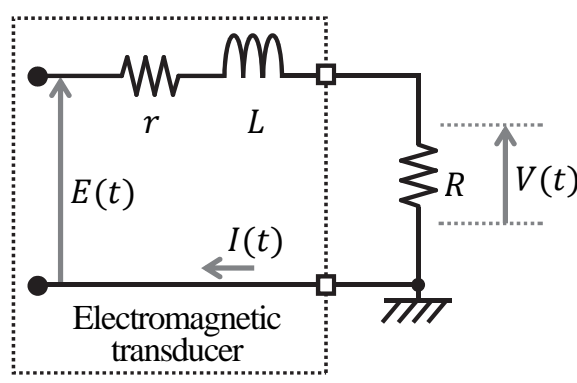

図-2 電磁誘導型発電装置の等価回路 


$$
R_{r}=\frac{R}{r}, \quad L_{r}=\frac{\omega L}{r}
$$

発電装置が吸収したエネルギーと発電したエネルギーの 比を変換効率hと定義すると, 次式のように表せる.

$$
h=\frac{R_{r}}{1+R_{r}}
$$

変換効率 $h$ は回路の抵抗值の比 $R_{r}$ に依存し, $R_{r}$ が大きい ほど1に近づく. 発電装置の力率 $P_{f}$ は次のようになる.

$$
P_{f}=\frac{1+R_{r}}{\sqrt{L_{r}^{2}+\left(1+R_{r}\right)^{2}}}
$$

$R_{r}$ と $L_{r}$ は変換効率と力率を用いて次のように表せる.

$$
\begin{gathered}
R_{r}=\frac{h}{1-h} \\
L_{r}=\frac{\sqrt{P_{f}^{-2}-1}}{1-h}
\end{gathered}
$$

はじめに, 電流の位相遅れが生じないモデルとして, 力 率 $P_{f}$ が1の場合を扱う. 図-1よりこのシステムの運動方 程式は次のように表される.

$$
m_{1} \ddot{x}_{1}+k_{1}\left\{x_{1}(t)-X(t)\right\}=-F_{e}(t)
$$

$$
\begin{aligned}
& M \ddot{X}(t)-k_{1}\left\{x_{1}(t)-X(t)\right\}+K X(t)+C_{M} \dot{X}(t) \\
& =F_{e}(t)+F(t)
\end{aligned}
$$

ここで，一般性を持たせるため，次の無次元項を導入す る.

$$
\begin{aligned}
& \zeta_{M}=\frac{C_{M}}{2 \sqrt{M K}}, \quad \zeta_{e}=\frac{c_{e}}{2 \sqrt{m_{1} k_{1}}} \\
& \mu_{1}=\frac{m_{1}}{M}, \quad \gamma_{1}=\frac{\sqrt{K / M}}{\sqrt{k_{1} / m_{1}}}, \quad \lambda=\frac{\omega}{\sqrt{K / M}}
\end{aligned}
$$

ただし，

$$
c_{e}=\frac{k_{e m f}^{2}}{r} \frac{1+R_{r}}{L_{r}^{2}+\left(1+R_{r}\right)^{2}}
$$

式(8)より, 減衰比 $\zeta_{e}$ は回路の抵抗比 $R_{r}$ を変化させること で数オーダーレベルの幅広い調整が可能である. なお, 同調質量系発電デバイスー橋梁間の減衰は発電電力に影 響を与えるものの, 本研究で行っている単質点系と二質 点系の比較という観点では影響を及ぼさないと考えられ ることから，本研究では同調質量系発電デバイス一橋梁 間の減衰の影響を検討対象としていない，ここで，無次 元項 $\overline{k_{e m f}}$ を導入すると $k_{e m f}$ は次のように表せる.

$$
k_{\text {emf }}=\overline{k_{\text {emf }}} \sqrt{\frac{\mu_{1}}{\gamma_{1}} r \sqrt{M K}}
$$

ただし，

$$
\overline{k_{e m f}}=\sqrt{2 \zeta_{e} \frac{L_{r}^{2}+\left(1+R_{r}\right)^{2}}{1+R_{r}}}
$$

ここで, 力 $F_{0}$ を静的に作用させた時の橋梁 $M$ の変位を静 的変位 $X_{0}$ と定義すると, 橋梁の定常振動変位の振幅 $X_{\text {max }}$ と $X_{0}$ の比である変位振幅比 $\overline{X_{\max }}$ は次のように表せる.

$$
\overline{X_{\max }}=\frac{X_{\max }}{X_{0}}=\frac{X_{\max }}{F_{0} / K}
$$

定常振動下において, 振動系に対寸る発電電力の振幅を 無次元化したものを発電電力比 $\overline{W_{\max }}$ と定義すると次の ように表せる。

$$
\overline{W_{\max }}=\frac{R I_{\max }^{2}}{F_{0}^{2} / \sqrt{K M}}
$$

以上より, 発電電流 $と$ 変位Xの伝達関数をラプラス変換 $(s=j \omega)$ より求めると次式のようになる.

$$
\begin{aligned}
& G I(s)=-\frac{M k_{e m f} \mu_{1} s^{3}}{D_{1}(s)+D_{2}(s)-d_{4}(s)} \\
& G X(s)=\frac{k_{e m f}^{2} s+d_{1}(s) d_{2}(s)}{D_{1}(s)+D_{2}(s)-d_{4}(s)}
\end{aligned}
$$

ただし，

$$
\begin{aligned}
& D_{1}(s)=k_{e m f}^{2} s\left\{d_{2}(s)+d_{3}(s)\right\} \\
& D_{2}(s)=d_{1}(s) d_{2}(s) d_{3}(s) \\
& d_{1}(s)=s L+r\left(R_{r}+1\right) \\
& d_{2}(s)=M \mu_{1} s^{2}+K \mu_{1} / \gamma_{1}^{2} \\
& d_{3}(s)=K+C_{M} s+M s^{2}+K \mu_{1} / \gamma_{1}^{2} \\
& d_{4}(s)=d_{1}(s) K^{2} \mu_{1}^{2} / \gamma_{1}^{4}+2 s K k_{e m f}^{2} \mu_{1} / \gamma_{1}^{2}
\end{aligned}
$$

単質点同調質量系発電デバイスの発電と制振の特性を考 えるため, 伝達関数より導かれるシステムの応答を用い て, 加振力の振動数比 $\lambda$ と減衰比 $\zeta_{e}$ に対寸る発電電力比 と変位振幅比の等高線図を図-3 2 図-4に示す。橋梁の減 衰比 $\zeta_{M}$ が発電デバイスのパラメータに与える影響は小さ く, ここでは一般的な鋼橋上部工の減衰比 0.02 とし, 質 量比 $\mu_{1}$ は0.0011 (1.1\%) とする. 質量比は後述する二質点 系の主マスと副マスの合計の質量比と等しくなるように 設定している. 図-3の赤い丸は発電電力比が極大となる 位置を示し，破線はそのときの $\zeta_{e}$ を示している．図-4の 青い丸は変位振幅比の極大值が最小となる位置を示し, 破線はそのときの $\zeta_{e}$ を示している.

図-5と図-6は $\zeta_{e}$ が0.01，0.03，0.05のときの発電電力比ス ペクトルと変位振幅比スペクトルを表している. 図-3と 図-5より，発電電力比は $\zeta_{e}$ に対して鋭敏であり， $\zeta_{e}$ のわ ずかな変化で発電電力比が急激に低下してしまう。その

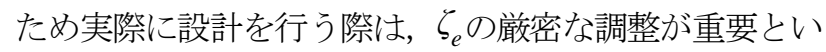
える. 図-3と図-4および図-5と図-6の比較より, 大きな発 


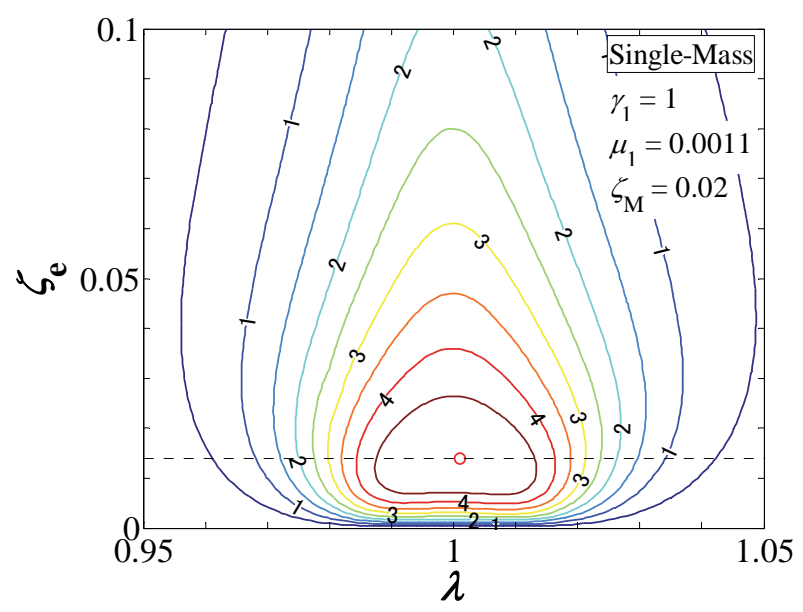

図-3 単質点系の減衰比と発電電力比スペクトルの等高線図

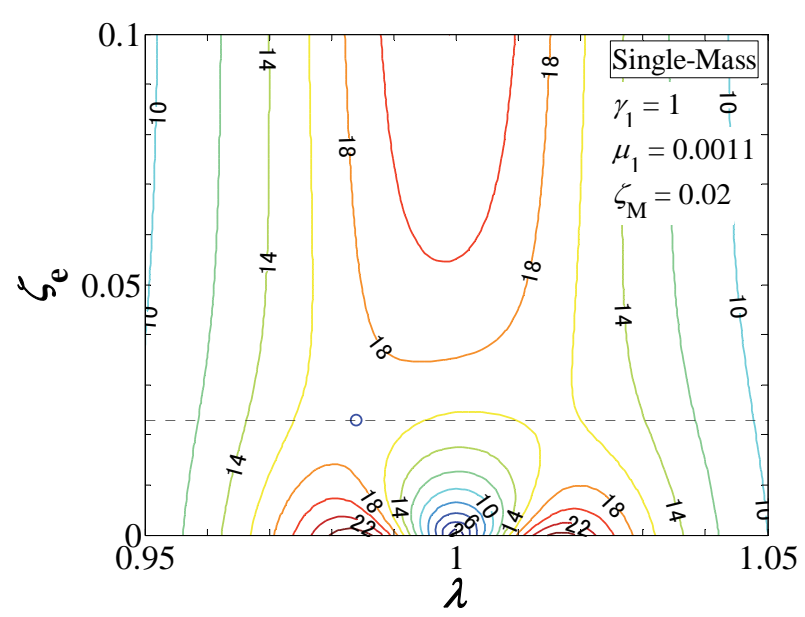

図-4 単質点系の減衰比と変位振幅比スペクトルの等高線図

電電力比スペクトルを与える $\zeta_{e}$ と小さな振幅比スペクト ルを与える $\zeta_{e}$ は一致しないことが分かる. 寸なわち単質 点同調質量系発電デバイスにおいて, 橋梁の振動制御を 目的とした設計と橋梁振動発電を目的とした設計では, パラメータの設計值が異なることを示している. なお， 本研究は伝達関数より導かれるシステムの応答に着目し ているため, これらの傾向は加振条件によらない傾向で あると考えることができる.

\section{3. 二質点同調質量系発電デバイス}

次に, 図-7に示す二質点系の同調質量系発電デバイス 一橋梁に関して解析を行う。すなわち, ばね定数Kのば ねと減衰定数 $C_{M}$ のダンパーで支持された橋梁の等価質 量 $M$ があり，等価質量 $M$ には，ばね，電磁誘導型発電装 置および2つの質量である主マス $m_{1}$ と副マス $m_{2}$ で構成 された二質点同調質量系発電デバイスが付加されている.

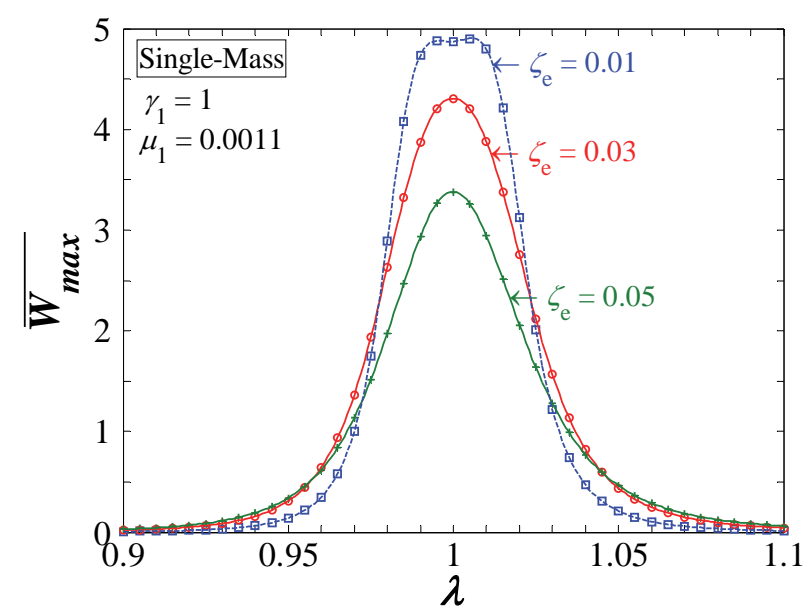

図-5 単質点系の減衰比変化と発電電力比スペクトル

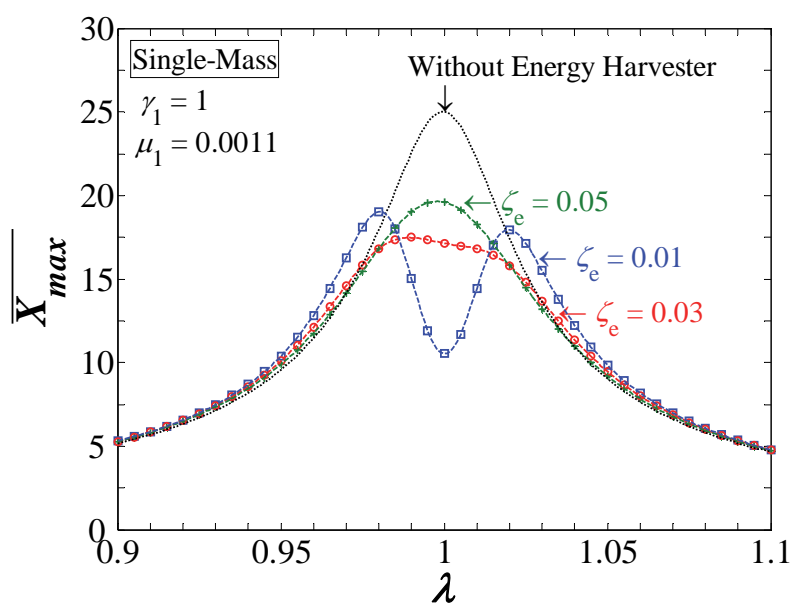

図-6 単質点系の減衰比変化と変位振幅比スペクトル

質量 $M$ に調和外力 $F(t)=F_{0} \sin (\omega t)$ が作用した時, 質量 $M の$ 変位を $X(t)$, 二質点同調質量系発電デバイスの $m_{1}, m_{2}$ の変位を $x_{1}(t), x_{2}(t)$ とする. このシステムの運動方程式 は次のようになる。

$$
\begin{gathered}
m_{1} \ddot{x}_{2}(t)+k_{2}\left\{x_{2}(t)-x_{1}(t)\right\}=-F_{e}(t) \\
m_{1} \ddot{x}_{1}(t)+k_{1}\left\{x_{1}(t)-X(t)\right\} \\
-k_{2}\left\{x_{2}(t)-x_{1}(t)\right\}=+F_{e}(t) \\
M \ddot{X}(t)-k_{1}\left\{x_{1}(t)-X(t)\right\} \\
-K X(t)+C_{M} \dot{X}(t)=F(t)
\end{gathered}
$$

ここで，一般性を持たせるため，単質点系で用いた無 次元項に加えて次の無次元項を導入する.

$$
\mu_{2}=\frac{m_{2}}{m_{1}}, \quad \gamma_{2}=\frac{\sqrt{k_{2} / m_{2}}}{\sqrt{k_{1} / m_{1}}}, \quad \zeta_{e}=\frac{c_{e}}{2 \sqrt{m_{2} k_{2}}}
$$

ただし， 


$$
k_{\text {emf }}=\overline{k_{\text {emf }}} \sqrt{\frac{\mu_{1} \mu_{2} \gamma_{2}}{\gamma_{1}} r \sqrt{M K}}
$$

発電装置の等価回路と抵抗 $R$ を有する同調質量系発電 デバイスの電気回路は図-2に示した. ここで, 減衰係数 $c_{e}$

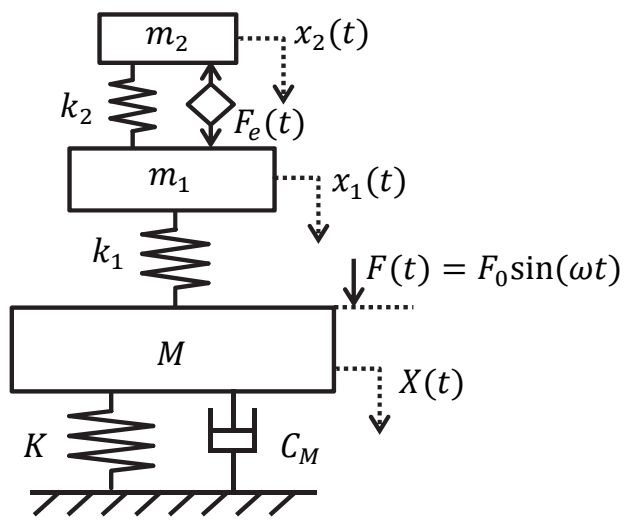

図-7 二質点同調質量系発電デバイスの解析モデル

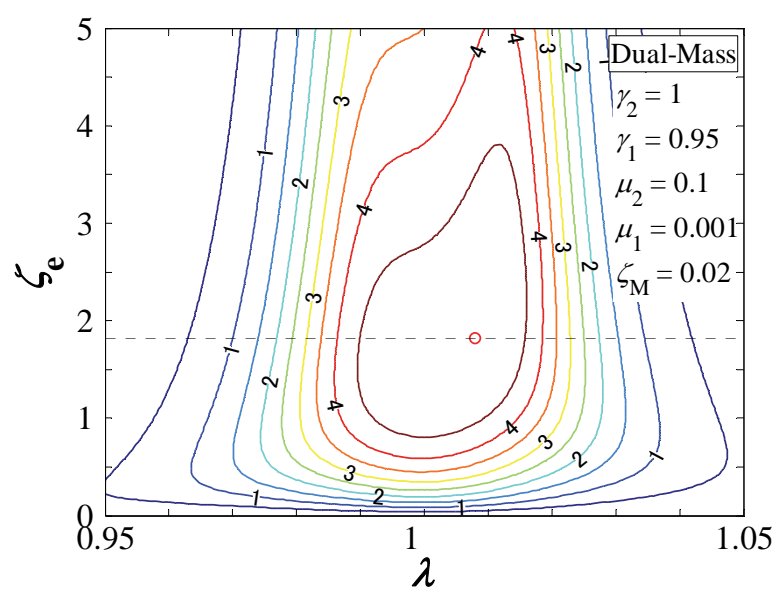

図-8 二質点系の減衰比と発電電力比スペクトルの等高線図

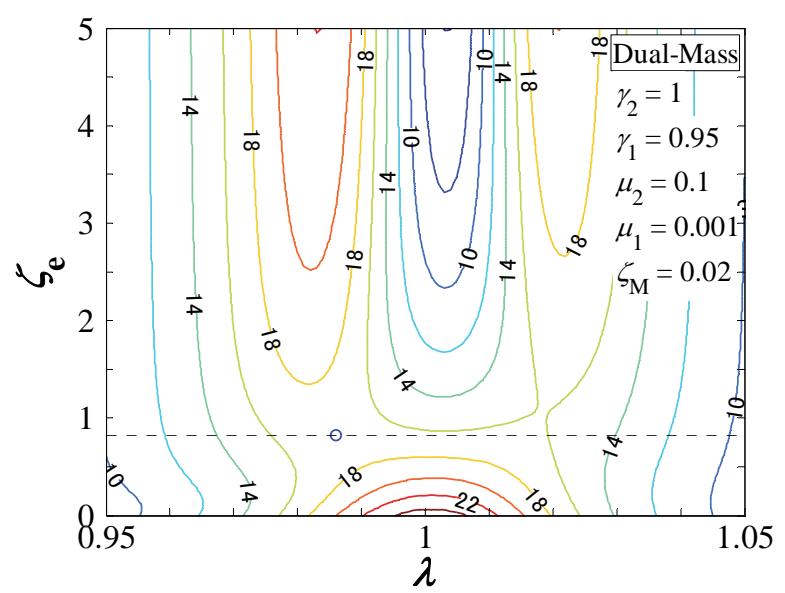

図-9 二質点系の減衰比と変位振幅比スペクトルの等高線図
は式(8)で表されることから，減衰比 $\zeta_{e}$ は回路の抵抗比 $R_{r}$ を変化させることで数オーダーレベルの幅広い調整が可 能である.

発電電流 $I$ 変位 $X$ の伝達関数をラプラス変換 $(s=j \omega)$ より求めると次式のようになる.

$$
\begin{aligned}
& G I(s)=-\frac{s^{3} M K k_{e m f} \mu_{1}^{2} \mu_{2} / \gamma_{1}^{2}}{D_{1}^{\prime}(s)+D_{2}^{\prime}(s)-D_{3}(s)-D_{4}(s)} \\
& G X(s)=\frac{\left\{D_{1}^{\prime}(s)+D_{2}^{\prime}(s)-D_{4}(s)\right\} / d_{3}(s)}{D_{1}^{\prime}(s)+D_{2}^{\prime}(s)-D_{3}(s)-D_{4}(s)}
\end{aligned}
$$
ただし，

$$
\begin{aligned}
& D_{1}^{\prime}(s)=k_{e m f}^{2} d_{3}(s)\left\{d_{2}^{\prime}(s)+d_{5}(s)\right\} s \\
& D_{2}^{\prime}(s)=d_{1}(s) d_{2}^{\prime}(s) d_{3}(s) d_{5}(s) \\
& D_{3}(s)=K^{2} \mu_{1}^{2} / \gamma_{1}^{4}\left\{d_{1}(s) d_{2}^{\prime}(s)+k_{e m f}^{2} s\right\} \\
& D_{4}(s)=d_{3}(s) d_{4}^{\prime}(s)
\end{aligned}
$$

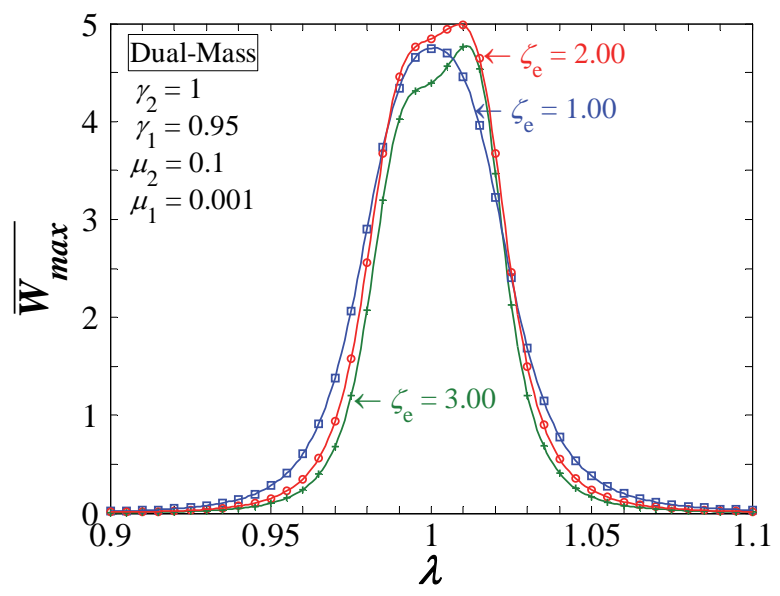

図-10 二質点系の減衰比と発電電力比スペクトル

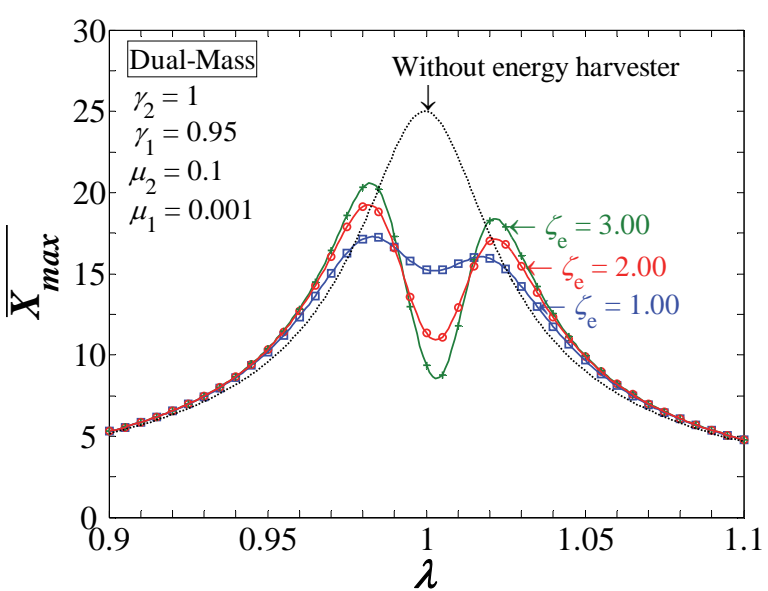

図-11 二質点系の減衰比と変位振幅比スペクトル 


$$
\begin{aligned}
& d_{2}^{\prime}(s)=M \mu_{1} \mu_{2} s^{2}+K \mu_{1} \mu_{2} \gamma_{2}^{2} / \gamma_{1}^{2} \\
& d_{4}^{\prime}(s)=d_{1}(s) K^{2} \mu_{1}^{2} \mu_{2}^{2} \gamma_{2}^{4} / \gamma_{1}^{4}+2 k_{e m f}^{2} K \mu_{1} \mu_{2} \gamma_{2}^{2} / \gamma_{1}^{2} s \\
& d_{5}(s)=d_{2}(s)+K \mu_{1} \mu_{2} \gamma_{2}^{2} / \gamma_{1}^{2}
\end{aligned}
$$

加振力の振動数比 $\lambda$ と減衰比 $\zeta_{e}$ に対寸る発電電力比々 変位振幅比を図-8と図-9に示す。ここでは，主マスの橋 梁に対する質量比 $\mu_{1}$ は0.001 (1\%o)， $\mu_{2}$ は0.1としている. 振動数比 $\gamma_{1}=0.95, \gamma_{2}=1$ の場合を表している. 図-8の赤 い丸は発電電力比の極大值の位置を示しており，破線は そのときの減衰比 $\zeta_{e}$ を示している. 図-9の青い丸は振幅 比の極大值の最小值の位置を示しており, 破線はそのと きの減衰比を示している.

図-10は発電電力比スペクトル，図-11は変位振幅比ス

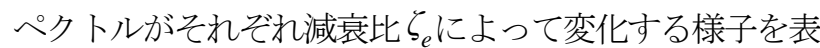
している. 図-8と図-10より，二質点系は単質点系に比べ て発電電力比が $\zeta_{e} に$ 対して鋭敏ではないことが分かる. その理由として，副マス $m_{2}$ の発電による減衰は，橋梁一 質量 $m_{1}$ 間のエネルギー伝達に与える影響が小さいこと

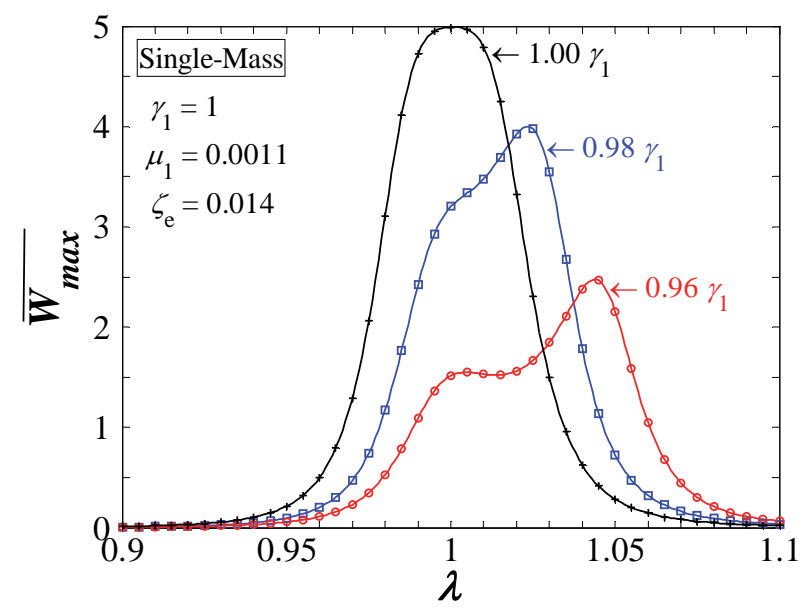

図-12 単質点系における発電電力比スペクトルの振動数 比による影響

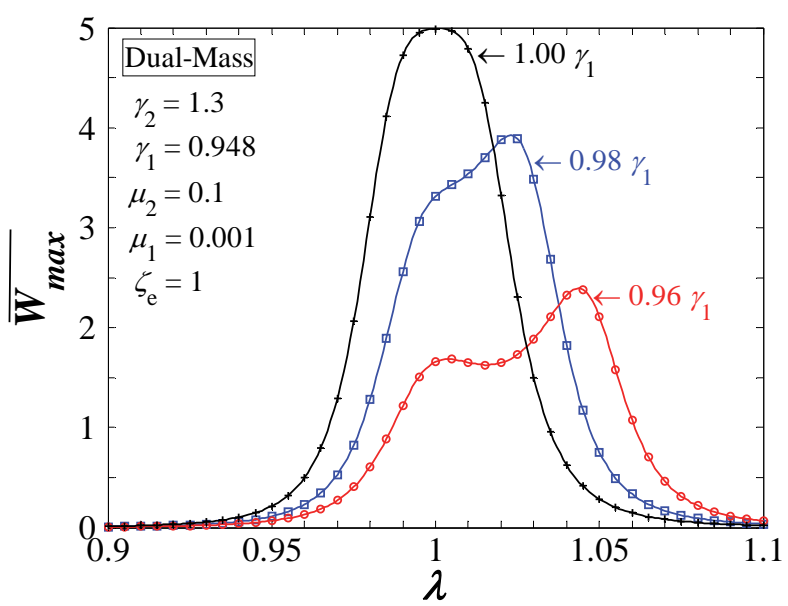

図-13 二質点系における発電電力比スペクトルの振動数 比による影響
が考えられる，一方，図-9と図-11より，変位振幅比は発 電電力比に比べると $\zeta_{e}$ に対して比較的鋭敏であるが，単 質点系の変位振幅比よりは鋭敏性は小さい. 発電を目的 として実際に設計する際に $\zeta_{e}$ の厳密な調整は，単質点系 と比較すると重要性が低いと考えられる，バッテリーや キャパシタなどへの充電を想定した場合, 減衰力は振動 の大きさやバッテリー電圧に依存するため, 減衰比 $\zeta_{e}$ は 一定ではない，そのため, 発電電力比が $\zeta_{e}$ 変化に対して 鋭敏でない二質点同調質量系発電デバイスの方が単質点 系に比較して，充電を想定した場合でも効果的な発電や 振動制御が期待できる.

なお，ここまで発電電力を無次元量 $\overline{W_{\max }}$ として議論し ているが，発電性能の具体的なオーダーを示すため, 0.1 1mmオーダーの振動振幅を想定し，式(10)および図 -11より例として橋梁の等価質量200ton, 固有振動数 $1 \mathrm{~Hz}$, 外力 $F_{0}=1 \mathrm{kN}$ の場合を考えると, 式(11)より図-10のスペ クトルはW（ワット）オーダーの発電電力となることを 示している.

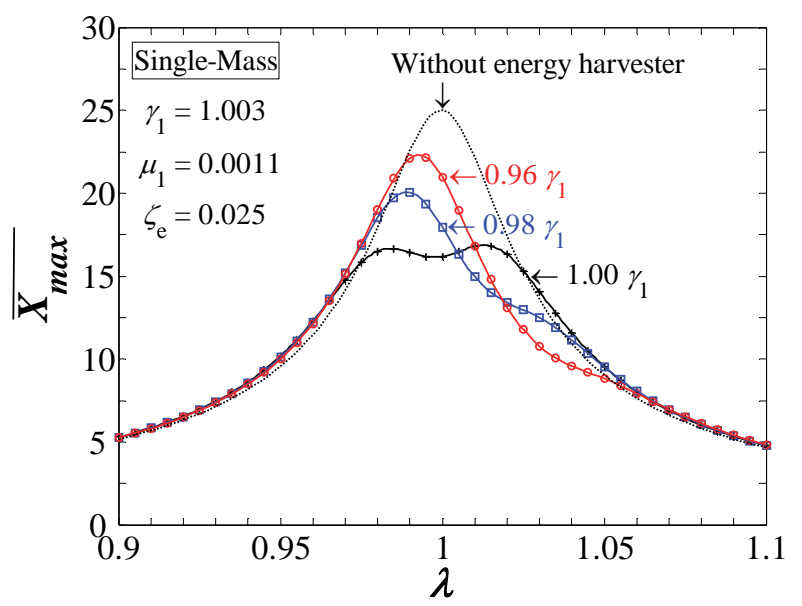

図-14 単質点系における変位振幅比スペクトルの 振動数比による影響

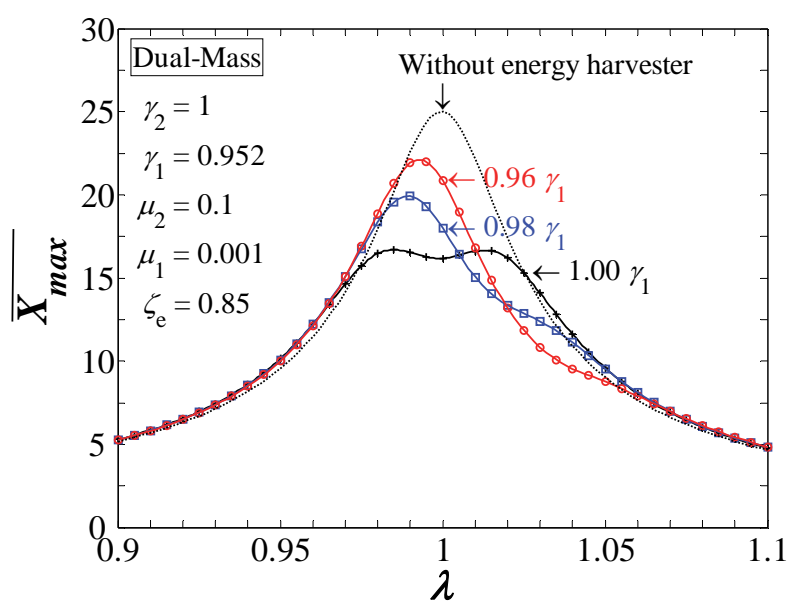

図-15 二質点系における変位振幅比スペクトルの 振動数比による影響 


\section{4. 単質点系と二質点系の比較}

\section{(1) 振動数比 $\gamma_{1}$ に対するスペクトル変化}

橋梁の固有振動数の微変動を想定し, 単質点と二質点 同調質量系発電デバイスの振動数比 $\gamma_{1}$ が微変動した場合 の発電電力比スペクトルを図-12と図-13に，変位振幅比 スペクトルを図-14と図-15にそれぞれ示す。ここでは $\gamma_{1}$ の変動前と $2 \%$ 減少, $4 \%$ 減少の場合のスペクトルを示し ている. $\gamma_{1}$ が減少すると発電電力比のスペクトルは右に シフトし，そのピーク值も減少することが分かる．橋梁 の固有振動数の変化に合わせてTMDの質量やばね定数 を調整することで $\gamma_{1}$ を調整することも考えられるが，一 般にTMDの大きな質量やばねを橋梁の現場で交換や調 整を行うことは困難である．単質点系の場合，比較的簡 単に調整できるパラメータは減衰比 $\zeta_{e}$ である. しかしな がら, $\zeta_{e}$ は発電電力比や変位振幅比のピーク值の大きさ を変化させるが，ピークの位置を移動させることはでき
ないため， $\gamma_{1}$ の変化に対する調整方法としては効果的で はない，二質点系においても単質点系と同様に， $\gamma_{1}$ が減 少すると発電電力比スペクトルは右に移動し，ピーク值 が減少する.また，変位振幅比スペクトルの左のピーク 值が増加し，振動制御性能は失われてしまう。しかしな がら二質点系の場合，質量の小さい $\mu_{2}$ に関するパラメー 夕は調整が比較的容易で現場での調整が可能と考えると， $\mu_{2}$ の調整でスペクトルのピーク位置を移動できる．ピー ク值の大きさは $\gamma_{2}$ または $\zeta_{e}$ で調整できるため, $\gamma_{1}$ が変化 した場合も $\mu_{2}$ と $\gamma_{2}$ または $\zeta_{e}$ の調整で対応できる.

図-16と図-17は二質点系において $\gamma_{1}$ の変化の影響を考 慮したパラメータ調整後の発電電力比と変位振幅比スペ クトルをそれぞれ示している.ここでは $\gamma_{1}, \mu_{1}, \zeta_{e}$ は固 定值として， $\gamma_{2}$ と $\mu_{2}$ を $\gamma_{1}$ の変化に合わせてそれぞれ調整 した值を用いている. 一般にTMDは振動数比に対して鋭 敏であるが，実際に調整を行う際には様々な制約のため パラメータ值を設計值と一致できることはまれであり,

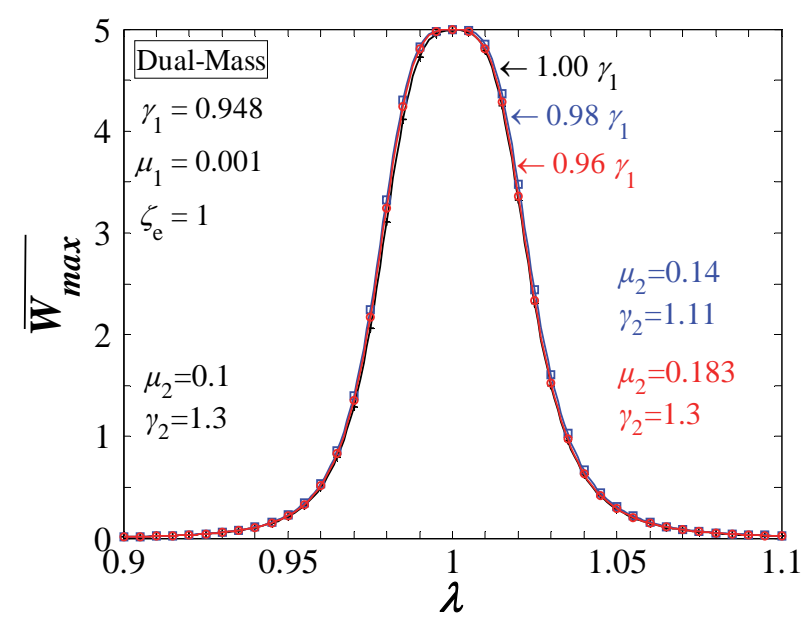

図-16 二質点系における振動数比による影響を考慮し たパラメータ調整後の発電電力比スペクトル

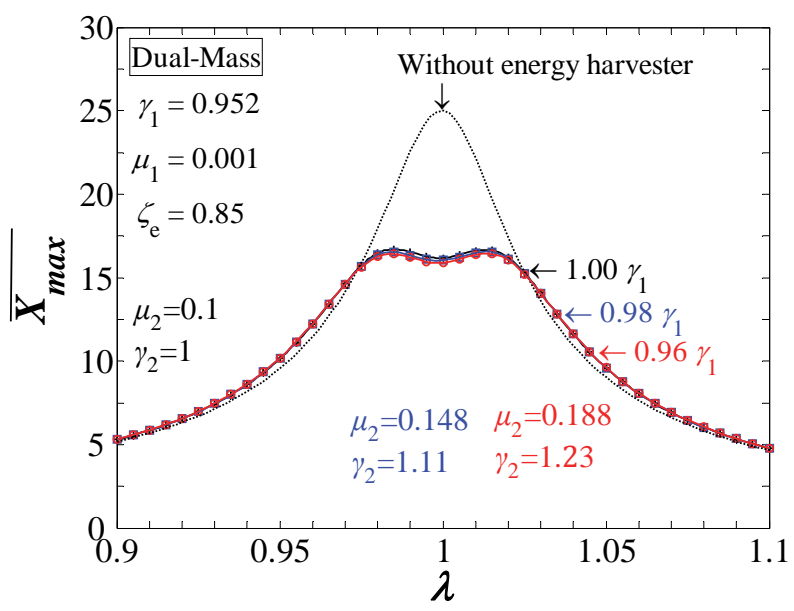

図-17 二質点系における振動数比による影響を考慮し たパラメータ調整後の変位振幅比スペクトル

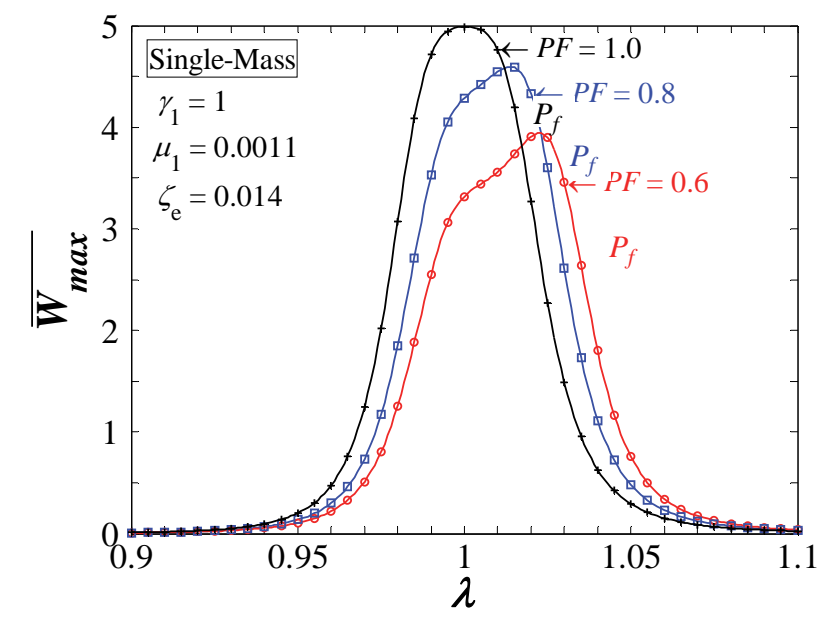

図-18 単質点系における発電電力比スペクトルの力率に よる影響

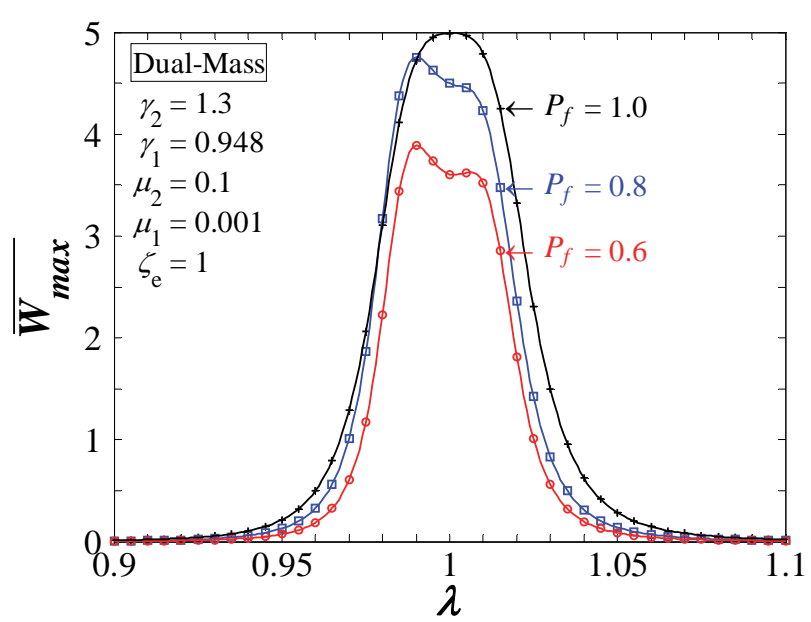

図-19 二質点系における発電電力比スペクトルの力率に よる影響 
その意味でも現場での微調整が重要であった. そのため, 現場での調整が比較的容易に行えるバラメータが多い二 質点同調質量系発電デバイスは単質点系に比べて現場適 用性の観点で有利といえる.

\section{(2) 力率 $P_{f}$ に対するスペクトル変化}

電磁誘導型の発電装置はコイルに起因する電圧と電流 の位相差が発生するため, 力率 $P_{f}$ は一般に $100 \%$ ではな い. 図-18と図-19は $P_{f}$ を変化させた時の, 単質点系と二 質点系の同調質量系発電デバイスの発電電力比スペクト ルを表している．単質点系と二質点系ともに力率が低下 すると発電電力比スペクトルのピーク值が低下し，特に 単質点系ではスペクトルが横方向にシフトしていること が分かる，そのため，同調質量系発電デバイスの設計に おいて，力率を考慮することが重要である．力率を考慮 した設計として次の2つが考えられる.

a) 力率改善回路の導入

b) 力率を考慮したパラメータ調整

a)は電気回路に力率改善回路 (Power Factor Correction: PFC）として図-20のようにコンデンサCを直列に繋ぎ, 発電装置内部のコイルによる遅れ位相をコンデンサの進

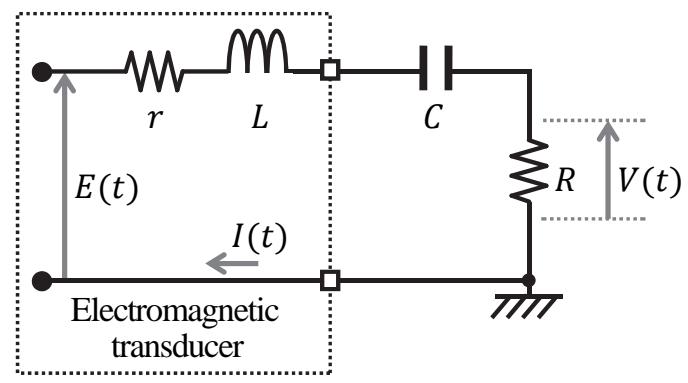

図-20 力率改善用キャパシタを含む回路

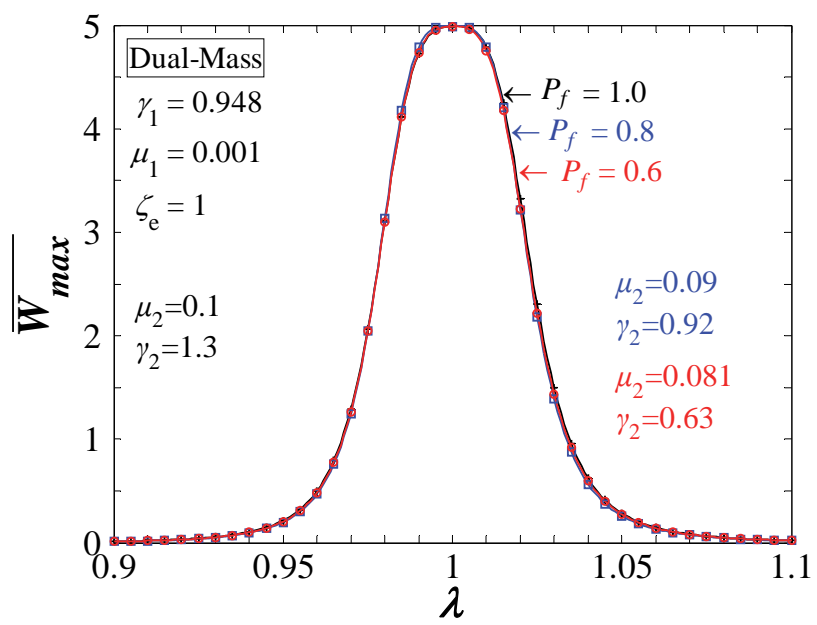

図-21 二質点系における力率による影響を考慮したパラ メータ調整後の発電電力比スペクトル

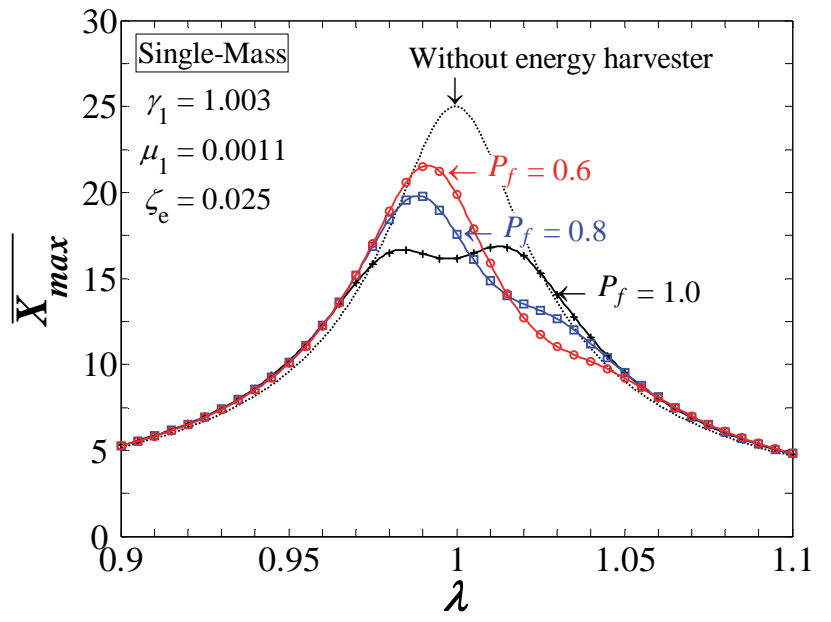

図-22 単質点系における変位振幅比スペクトルの力率に よる影響

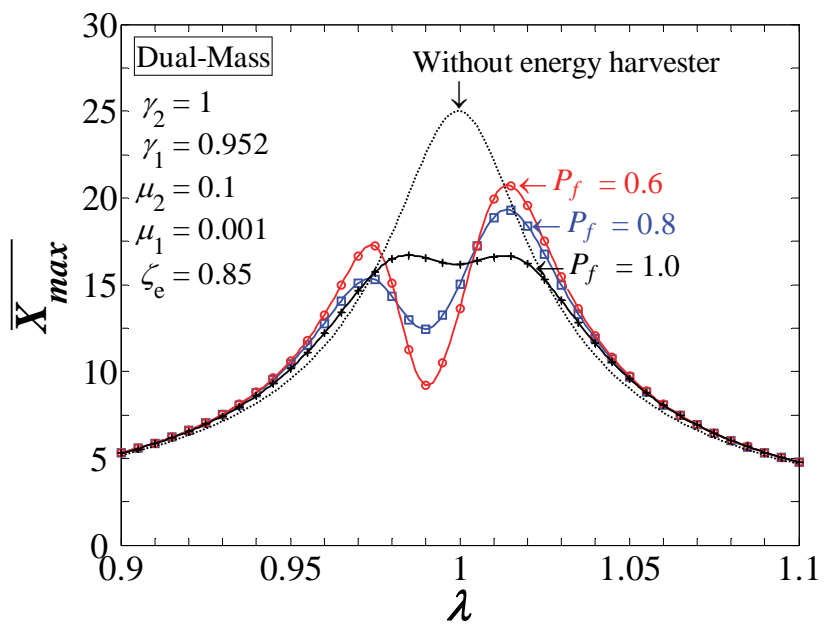

図-23 二質点系における変位振幅比スペクトルの力率に よる影響

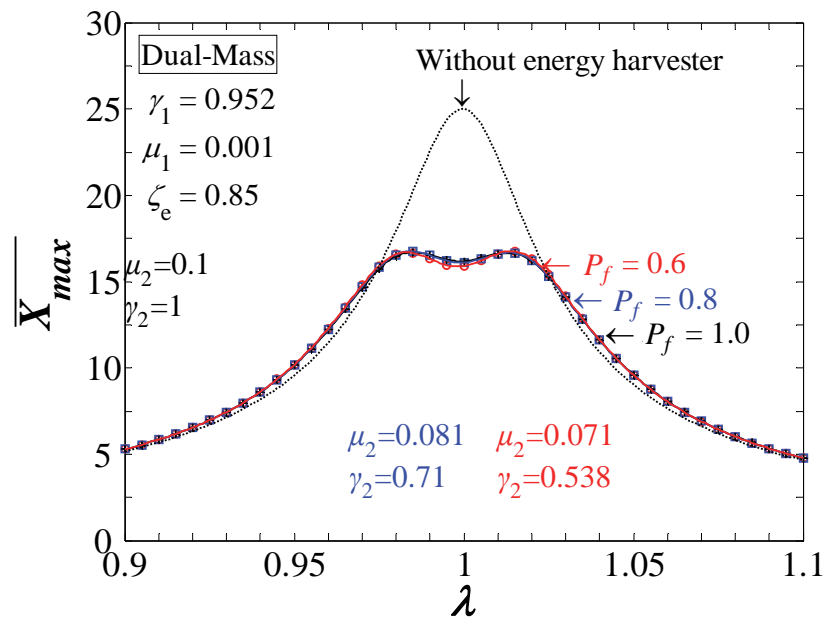

図-24 二質点系における力率による影響を考慮したパラ メータ調整後の変位振幅比スペクトル 
み位相で打ち消寸ことで力率を1に近づける方法である. このとき回路の力率 $P_{f}$ は次式で表される.

$$
P_{f}=\frac{1+R_{r}}{\sqrt{\left(L_{r}-C_{r}\right)^{2}+\left(1+R_{r}\right)^{2}}}
$$

ただし，

$$
C_{r}=\frac{1}{\omega r C}
$$

$C_{r}$ は無次元化されたコンデンサの静電容量である. 式 (16)より, 力率が1となるのは $C_{r}=L_{r}$ のときである. 力率 改善回路の設計では発電装置内部のコイルのインダクタ ンス $L$ が既知であることが必要となる.

b)の力率を考慮したパラメータ設計に関して，図-21に 示すように二質点系の発電電力比スペクトルはパラメー 夕設計によって力率 $100 \%$ の場合のスペクトルと等しく できることがわかる．単質点系の場合 $\gamma_{1}$ を調整できれば 力率100\%の場合のスペクトルと等しくなるが，二質点系 の場合は $\gamma_{1}$ を調整する必要がなく $\mu_{2}, \gamma_{2}$ または $\zeta_{e}$ を調整 すればよい. 二質点系では調整が比較的容易なパラメー 夕のみを用いて力率を考慮した調整ができるため，単質 点系に比へて適用性が高いといえる.

$P_{f}$ を変化させた時の変位振幅比スペクトルを表してい る図-22と図-23においても，単質点系と二質点系ともに 力率が低下寸ると変位振幅比スペクトルのピーク值が上 昇し, 制振機能が失われてしまう. 変位振幅比スペクト ルに関して力率を考慮した二質点系のパラメータ設計を 行ったものを図-24に示す. 発電電力比スペクトルと同様, パラメータ設計によって力率100\%の場合と等しくでき ることがわかる。

\section{5. 結論}

本研究では, 橋梁振動を対象とした環境発電デバイス （Energy Harvester）として，TMDのダンパーを電磁誘導 型の発電装置に置き換えた同調質量系発電デバイスを考 え, 単質点と二質点の同調質量系発電デバイスのモデリ ングを提案し，それらの比較から有利な装置構成につい て検討を行い, 制振と発電効率の減衰比や橋梁の固有振 動数変化に対する鋭敏性，力率による影響など同調質量 系発電デバイスの設計に関する特性を検討した結果, 得 られた知見を以下に示す.

(a) コイルを有する等価回路で電磁誘導型発電装置を表 現し, ダッシュポッドモデルを用いずに発電装置の 減衰力を回路式より導くことで, 発電装置の力率に 起因寸る減衰力の位相遅れが発電電力や振動制御に 与える影響を考慮したモデリングを提示した.

(b) 運動方程式と回路式を用いて, 単質点と二質点同調
質量系発電デバイスの発電電力比々変位振幅比の 伝達関数を示した. その結果, 二質点系は発電電力 比が減衰比に対して比較的鋭敏でないことを示し， 減衰比が変化する充電回路において二質点系は効 果的な発電や振動制御が行えることを示した.

(c) 橋梁の振動制御を目的とした設計と, 振動発電を目 的とした設計では設計值が異なることを明らかに し, 減衰比の調整によって制振と発電のバランスを 目的に合わせて設計できることを示した.

（d）発電を目的とした場合，二質点系は比較的容易に調

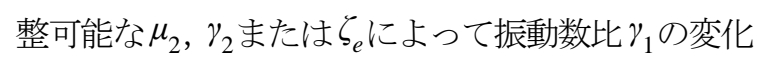
に対応できることを導き, 調整可能なパラメータが 多い二質点系が単質点系に比べて現場適用性の観 点で有利であることを示した.

(e) 力率を考慮した設計が重要であることを導き，力率 改善回路を用いる設計方法と同調質量系発電デバ イスのパラメータ調整によって設計する方法をそ れぞれ提示した. 力率の影響を考慮した設計におい て，二質点系は調整が容易なパラメータを多く有す るため, 現場適用性が高いことを示した.

本研究より，0.1 1mmオーダーの振動振幅を想定し, 橋梁の等価質量200ton, 固有振動数 $1 \mathrm{~Hz}$, 外力 $F_{0}=1 \mathrm{kN}$ の 場合を考えると, ワットオーダーの発電電力が期待でき ることが示された. バッテリーなどへの充電回路を含め た同調質量系発電デバイスでは, 強い非線形性のため加 振力の履歴と大きさによって発電や振動制御の効果が異 なる. これを今後解決することで, 橋梁振動を対象とし たより高効率な発電が可能になると考えられる.

\section{参考文献}

1) 吉田善紀, 小林裕介, 内村太郎 : 鋼鉄道橋の振動発電 を利用したモニタリングシステムの開発, 土木学会論 文集 A, Vol. 70, No.2, pp.282-294, 2014.

2) 長船寿一, 中村俊一, 水野惠一郎, 加藤久雄, 上田知 孝: 道路橋振動対策としての運動量交換型衝撃吸収ダ ンパーの研究, 構造工学論文集 A, Vol.56A, pp.237-250, 2010.

3) 吉田善紀, 小林裕介, 和田一範 : 鋼鉄道橋の振動発電 を利用した充電手法の動態観測モニタリングへの適 用, 構造工学論文集 A, Vol.61A, pp.532-543， 2015.

4) 井上竜太: 振動発電を利用したエコ工事振動対策技術 の開発，竹中技術研究報告, No.68, pp.1-8, 2012.

5) 井上竜太, 安倍隆之, 平林信二: 空調設備の振動発電 利用に関する研究 その 2 振動発電デバイスと低消費 電力型無線センサモジュールを用いた検証試験, 日本 建築学会大会学術講演梗概集, pp.1351-1352, 2013.

6) Cassidy, I. L., Scruggs, J. T., Behrens, S. and Gavin, H. P. : Design and experimental characterization of an electromechanical transducer for large-scale vibratory energy harvesting applications, Journal of Intelligent Material Systems and Structures, Vol. 22, No. 17, pp. 2009-2024, 2011. 
7) Shen, W., Zhu, S. and Xu, Y. : An experimental study on self-powered vibration control and monitoring system using electromagnetic TMD and wireless sensors, Sensors and Actuators A, Vol. 180, pp. 166-176, 2012.

8) 田中実, 鈴木正夫 : 地上コイル異常検知センサ用給電 装置の開発，鉄道総研報告，Vol.27，No.7，pp.17-22， 2013.

9) Zhu, S., Shen, W. and Xu, Y. : Linear electromagnetic devices for vibration damping and energy harvesting: Modeling and testing, Engineering Structures, Vol. 34, pp. 198-212, 2012.

10) Arroyo, E., Badel, A., Formosa, F., Wu, Y. and Qiu, J. : Comparison of electromagnetic and piezoelectric vibration energy harvesters: Model and experiments, Sensors and Actuators, Vol. 183A, pp. 148-156, 2012.

11) 山口浩, 佐々木栄一, 峰沢ジョージヴゥルペ: エレク トレット振動発電素子を用いたパッシブ型振動速度 センサの開発，土木学会論文集 A, Vol.70, No.2, pp.150-160, 2014.

12) Suzuki, Y., Miki, D., Edamoto, M. and Honzumi, M. : A MEMS electret generator with electrostatic levitation for vibration-driven energy-harvesting applications, Journal of Micromechanics and Microengineering, Vol. 20, No. 10, 2010.

13）赤澤輝行, 村尾景司, 岡田幸弘 : フリーピストンスタ ーリングエンジン用リニア発電機の研究, 日本機械学 会 [No.05-39]，第 9 回スターリングサイクルシンポ ジウム講演論文集, pp.33-34, 2005.

14）星野健, 吉原正一, 赤澤輝行, 村尾景司 : 新形式リ二 ア発電機の性能試験, 日本機械学会 [No.05-39]，第 10 回スターリングサイクルシンポジウム講演論文集, pp.109-110, 2006.

15) Liang, J. and Liao, W. : Impedance matching for improving piezoelectric energy harvesting systems, Active and Passive Smart Structures and Integrated Systems 2010, Vol. 7643, 2010.
16) Cassidy, I. L. and Scruggs, J. T. : Nonlinear stochastic controllers for power-flow-constrained vibratory energy harvesters, Journal of Sound and Vibration, Vol. 332, pp. 3134-3147, 2013.

17) Sgobba, S. and Marano, G. C. : Optimum design of linear tuned mass dampers for structures with nonlinear behavior, Mechanical Systems and Signal Processing, Vol. 24, pp. 1739-1755, 2010.

18) Lee, C., Chen, Y., Chung, L. and Wang, Y. : Optimal design theories and applications of tuned mass dampers, Engineering Structures, Vol. 28, pp. 43-53, 2006.

19) 堀内博, 藤沢伸光, 津村直宜: TMD の設計における 実用算定式，構造工学論文集 A, Vol. 37A, No.2, pp.781-788, 1991.

20) 吉住文太, 佐野健一, 井上浩男 : 少数個 TMD の最適 ロバスト設計, 構造工学論文集 A, Vol. 48A, No. 1, pp.329-338, 2002.

21) 阿部雅人, 藤野陽三 : マルティプル同調質量ダンパー (MTMD)の性能評価式, 土木学会論文集, No.465/I-23, pp.97-106, 1993.

22) 潘公宇, 安田正志: 多重動吸振器のロバスト最適設計 方法, 日本機械学会論文集 C 編, Vol.71, No.712, pp.96-102, 2005.

23) Foisal, A. R. M., Hong, C. and Chung, G. : Multi-frequency electromagnetic energy harvester using a magnetic spring cantilever, Sensors and Actuators A, Vol. 182, pp. 106-113, 2012.

24) Tang, $X$. and Zuo, L. : Enhanced vibration energy harvesting using dual-mass systems, Journal of Sound and Vibration, Vol. 330, pp. 5199-5209, 2011.

25) Tang, X. and Zuo, L. : Vibration energy harvesting from random force and motion excitations, Smart Materials and Structures, Vol. 21, pp. 1-9, 2012.

(2015. 2. 23 受付)

\section{CHARACTERISTICS INVESTIGATION OF TUNED MASS ENERGY HARVESTER FOR BRIDGE VIBRATION}

\section{Kouichi TAKEYA and Eiichi SASAKI}

A bridge vibration energy harvester has been proposed in this paper using a Tuned Mass Damper (TMD) system, named hereafter tuned mass energy harvester. To harvest and make use of the unused reserve of energy the aforementioned damper system absorbs, an electromagnetic transducer has been applied. To investigate the configuration of the tuned mass energy harvester considering performances of bridge vibration control and energy harvesting, single-mass and dual-mass systems where one or two masses are connected in series with the electromagnetic transducer and spring are proposed. According to the theory of vibrations and electric circuits, it has been clarified that dual-mass systems have several advantages over single-mass systems for power generation and vibration control. It has also been clarified that for effective energy harvesting or vibration control, it is essential to consider the power factor of electromagnetic transducer and electric circuit. 